\title{
AFTER THE REVOLUTION?
}

$($ OMEONE ELSE'S COUNTRY, $\checkmark$ Alister Barry's documentary film which was included in the seminar series 'After the Revolution?', notes that the New Right changes imposed in Chile - sale of assets and environment, privatising of hospitals, cutbacks in welfare and education - were brutally imposed by military force. Many of these same 'reforms' undertaken a decade later in New Zealand were efficiently put in place with little effective opposition. A central question underlying the changes in New Zealand, and these papers (and important in all Stout Centre work) is, what kind of a country is New Zealand? In observing the changes of the past decade can we still claim to be an established democracy with an egalitarian tradition and a commitment to fair play? The changes of the past decade not only alter the political and social landscape they alter our perceptions of ourselves and of New Zealand.

\section{NEW ZEALAND STUDIES \\ formerly the \\ Stout Centre Review \\ ISSN 1173-6348 \\ Director: Vincent O'Sullivan \\ Editor: Allan Thomas \\ Design \& production: Roger Joyce \\ Secretary: Sarah Upton \\ NEW ZEALAND STUDIES is a multi- \\ disciplinary journal reflecting the \\ research interests of the Stout Research \\ Centre, Victoria University of \\ Wellington. \\ MEMBERSHIP of the Stout Centre is \\ $\$ 35$. This supports the work of the \\ Centre, entitles participation in \\ seminars and other activities and \\ includes subscription to New Zealand \\ Studies. \\ ADDRESS all inquiries to: \\ The Secretary, Stout Research Centre \\ Victoria University of Wellington \\ PO Box 600, Wellington, New Zealand. \\ Telephone +64-4-4715305 \\ Facsimile +64-4-4965439}

We were of course distracted by other issues, notably the Nuclear Free issue, seduced by the new technology ('computers can do it better'), and blinded by the haste and certainty of the New Right ideologues. Not an argumentative people or given much to intellectual debate we were at a disadvantage when faced with the born-again crusaders. The economic and social changes of the decade were commonly promoted as cost-saving changes for efficiency but it became clear that they were ideologically driven and their consequences far greater than those at first specified.

This short seminar series occured in March-April 1997 after the establishment of the National/NZ First Coalition Government, in a period of uncertainty: Would structural reform and asset sales continue? Would the mistakes of the past be admitted and revisited? Had we reached the end of the revolution or was this just a lull, a tea-break? At this time the ideology seemed more defensive, the 'reforms' slower, perhaps an element of uncertainty was creeping in. The opportunity for reflection and analysis was accepted by these writers. The Stout Centre is grateful for their contribution.

A consistent critique of the changes has been supplied by our cartoonists. We are pleased to be able to include some of their work here, both to lighten an otherwise sombre story and to evidence their vision. Grateful acknowledgement is made for permission to use their original work (and to the publication where the work first appeared) to Bob Brockie (National Business Review), Lawrence Clark (New Zealand Herald), Tom Scott (Evening Post), and Garrick Tremain (Otago Daily Times). All cartoons are reproduced from copies supplied by the Alexander Turnbull Library.

Allan Thomas

\section{CONTRIBUTORS TO THIS ISSUE}

BRIAN EASTON, an Associate of the Stout Research Centre, researches, writes, and teaches in the areas of economics, social statistics and public policy. His Commercialisation of New Zealand is reviewed in this issue (page 39), and In Stormy Seas, a history of the post war economy will be published later this year.

ANNE ELSE, a former resident of the Stout Research Centre (1988-89), is an independent researcher, writer and broadcaster specialising in gender issues in the post-war period. Her latest book, False Economy: New Zealanders Face the Conflict between Paid and Unpaid Work, was published by Tandem Press in 1996.

JANE KELSEY, author of the New Zealand Experiment: A Model for World Structural Adjustment? reviewed in this issue (page 37), is Associate Professor of Law at the University of Auckland.
TONY SIMPSON has worked in the public sector for over 30 years and has been variously a journalist, industrial advocate, arts administrator, strategic planner, and most recently a policy analyst with the Parliamentary Services Commission. For seven years from 1990 he was a member of the council and national executive of the New Zealand Public Service Association, three of those years as president. $\mathrm{He}$ is also the author of 12 published works, mostly dealing with aspects of New Zealand's social and political history.

JIM TRAUE, a former Chief Librarian of the Alexander Turnbull Library, is the Teaching Fellow in Victoria University's School of Communications \& Information Management. He has been active through the Archives \& Records Association and the Friends of Wellington Public Libraries as an advocate for free access to public information. 